\title{
Enhanced Aqueous Arsenic Absorbing Substituted Spinel Nickel Ferrite $\left(\mathrm{NiFe}_{2} \mathrm{O}_{4}\right)$ Nano-Particles
}

\section{Muhammad Idrees* and Saima Batool}

MOE Key Laboratory of Space Applied Physics and Chemistry, Shaanxi Key Laboratory of Macromolecular Science and Technology, School of Science, Northwestern Polytechnical University, Xi'an, 710072, PR China

"Corresponding author: Idrees M, MOE Key Laboratory of Space Applied Physics and Chemistry, Shaanxi Key Laboratory of Macromolecular Science and Technology, School of Science, Northwestern Polytechnical University, Xi'an, 710072, PR China, Tel: +862988431621; E-mail: m.idrees8223@gmail.com

Received date: Mar 14, 2017; Accepted date: Mar 15, 2017; Published date: Mar 17, 2017

Copyright: ( 2017 Idrees M, et al. This is an open-access article distributed under the terms of the Creative Commons Attribution License, which permits unrestricted use, distribution, and reproduction in any medium, provided the original author and source are credited.

\begin{abstract}
Arsenic is noxious metal exist in water in form of organic dimethyl arsenic acid $\left(\mathrm{C}_{2} \mathrm{H}_{7} \mathrm{As} \mathrm{O}_{2}\right)$ and monomethylarsonic acid $\left(\mathrm{CH}_{5} \mathrm{AsO}_{3}\right)$ while in inorganic arsenic trioxide $\left(\mathrm{As}_{2} \mathrm{O}_{3}\right)$ and sodium arsenate $\left(\mathrm{NaH}_{2} \mathrm{AsO} \mathrm{O}_{4}\right)$. Its trivalent and pentavalent forms are abundant in natural water. Its trivalent form is 60 times more hazardous than pentavalent form. Reports proved that arsenic contamination in water is the basic reason behind many chronic health problems and its removal was the major concern issue. Versatile soft synthesized ferrite material was used as an efficient adsorbent to adsorb arsenic from drinking water in recent times. In these contribution, magnetic nanoparticles adsorbents $\left(\mathrm{NiFe}_{2} \mathrm{O}_{4}\right)$ have been synthesized by co-precipitation route using stable nickel salts and ferric with potassium hydroxide as the precipitating agent. Synthesized $\mathrm{NiFe}_{2} \mathrm{O}_{4}$ exhibits tetrahedral and octahedral sites having typical ferromagnetic and technologically properties and used as adsorbent. Nickel ferrite was well characterized by thermo gravimetric analysis (TGA), powder X-ray diffraction (XRD), energy dispersive X-ray spectroscopy (EDS) and field emission scanning electron microscope (FESEM). Adsorption of as using $\mathrm{NiFe}_{2} \mathrm{O}_{4}$ correlated well $\left(R^{2}>0.90\right)$ with the Freundlich isotherm. The analysis revealed that $98 \%$ arsenic has been removed from water by nickel ferrite which is much higher than other adsorbents.
\end{abstract}

Keywords: Adsorption; Nickel ferrite nanoparticles; Isotherms; Aqua-treatment; Removal efficiency

\section{Introduction}

Arsenic "As" is noxious earth metal exist both in organic and inorganic form causing huge contamination in natural water. It has hazardous chronic and acute effects on human body mainly causes muscle pain, abdominal pain, weakness, diarrhea, skin pigmentation, hair loss, liver cancer, birth defects, cardiovascular, reproductive and nervous problems. The provisional permissible level of arsenic concentration, in view of scientific uncertainties surrounding the risk assessment for arsenic carcinogenicity per the world Health Organization (WHO) in drinking water is $50 \mathrm{ppb}$. [1] It exists in nature in combine form with sulfur, oxygen and iron. [2] It exists in four oxidation states: As (-III), As (0), As (+III) and As (+V). Arsenic in trivalent and pentavalent forms is most abundant in natural water. Its trivalent form is 60 times more hazardous than pentavalent form. In purification of water it is essential to change trivalent form of arsenic into pentavalent form. Due to biological activities and industrial contaminations organic forms of arsenic has prime role to poison ground water reservoir [3].

Also, arsenic is contaminating natural water through mining of the ores. Water deposit of sediments and rocks not only contain arsenic, it also consists an adequate amount of dissolved oxygen, discharge of arsenic occur when sediments come close to oxygen-deficient groundwater. Natural phenomena's such as floods, landslides and presence of heavy metals such as arsenic, boron, uranium in ground or surface water are also participating in it. [4] Different convectional techniques such as boiling, chlorination and solar disinfection are suggested as the cheap methods to purify the water at household level.
[5] Adsorption method is one of the suitable easy handling process to remove arsenic contaminants using adsorption medium. Different adsorbents such as silica gel, activated alumina, carbons, zeolites, polymer and resins, clay, rice husk carbon is used to remove arsenic contaminants from water. However, increasing arsenic hazardous health effect and cost-synthesized adsorbent supplies surged the interest of advanced synthesized magnetic material. Nano-sized spinel ferrite particles, a soft synthesized magnetic material with structural formula of $\mathrm{MFe}_{2} \mathrm{O}_{4}$ are one of the most attracting class of adsorbent materials due to their interesting and important properties such as high melting point, towering heat, large expansion coefficient, squat dispersion magnetic moment and low magnetic transition temperature, etc., [6,7] Due to these properties, the spinel ferrites have many technical applications, such as in photoelectric devices, catalysis, sensors, nano-devices, microwave devices and magnetic pigments. [8-14]

Remarkable electrical and magnetic properties of ferrites depend upon the nature of the ions, their charges and their distribution among tetrahedral (A) and octahedral (B) sites. [15] Nickel ferrite is one of the versatile and technologically important soft ferrite materials because of its typical ferromagnetic properties, low conductivity and thus lower eddy current losses, high electrochemical stability, catalytic behavior, abundance in nature, etc., [16] This ferrite is an inverse spinel in which eight units of $\mathrm{NiFe}_{2} \mathrm{O}_{4}$ go into a unit cell of the spinel structure. Half of the ferric ions preferentially fill the tetrahedral sites (A-sites) and the others occupy the octahedral sites (B sites). [17] Thus, the compound can be represented by the formula $\left(\mathrm{Fe}^{3+}\right) \mathrm{A}\left[\mathrm{Ni}^{2+} \mathrm{Fe}^{3+}\right] \mathrm{BO}_{4}{ }^{2-}$. [18] The synthesis of spinel ferrite nanoparticles has been intensively studied in the recent years and the principal role of the preparation conditions on the morphological and structural features of the ferrites is discussed. [19-20] Large-scale applications of ferrites with small particles and 
tailoring of specific properties have prompted the development of widely used chemical methods, including hydrothermal, sonochemical reactions, sol-gel methods, microwave plasma, co-precipitation, micro emulsion methods, citrate precursor techniques [21-27] for the fabrication of stoichiometric and chemically pure spinel ferrite nanoparticles. In present study, we used synthesized soft magnetic $\mathrm{NiFe}_{2} \mathrm{O}_{4}$ material by co-precipitation as an efficient adsorbent arsenic agent from aqueous environment due to its different technological application. present study, we used synthesized soft magnetic $\mathrm{NiFe}_{2} \mathrm{O}_{4}$ material by co-precipitation as an efficient adsorbent arsenic agent from aqueous environment due to its different technological application.

\section{Experimental Section}

\section{Materials}

The ferric nitrate (97\%), nickel acetate (99\%) and potassium hydroxide $(>99 \%)$ were used as raw products, received by Merck $^{\circ}$ company to synthesize samples. Pyrex glass apparatus, hot-plate with magnetic stirrer (Staurt CB 162), $\mathrm{pH}$ meter, mortar and pestle, crucible and electrical furnace were used for investigation, maintain homogeneity and reaction mixture required temperature, solution $\mathrm{pH}$, grinding and annealing of different samples. Sodium borohydrate (98\%), sodium hydroxide hydrochloric acid (concentrated 37\%) and 1000 arsenic CRM were chemical reagents and used as received for the analysis.

\section{Synthesis of nickel ferrite $\left(\mathrm{NiFe}_{2} \mathrm{O}_{4}\right)$}

Ferrite nanoparticles were primed by the chemical coprecipitation method. For this purpose, the stoichiometric amounts of ferric nitrate $(0.2 \mathrm{M})$ and nickel acetate $(0.1 \mathrm{M})$ were dissolved in the deionized water. The molar ratio between the ferric and nickel was kept 2: 1 in the synthesis of $\mathrm{NiFe}_{2} \mathrm{O}_{4}$. These two solutions were assorted in a beaker and stimulated vigorously. The mixture was heated up to $323 \mathrm{~K}$ and then potassium hydroxide solution $(2 \mathrm{M})$ was added drop wise under constant vigorous rousing until the $\mathrm{pH}$ of the solution reached to 11-12. The precipitates formed were further stirred for 3 hours to maintain the homogeneity. These precipitates were then washed several times with deionized water until the $\mathrm{pH}$ reached to 7 and finally washed with methanol. The precipitates were dried at $373 \mathrm{~K}$ in an electric oven. The dried sample was grinded in mortar and pestle. The powder was then finally annealed at $1073 \mathrm{~K}$ for 8 hours in an electrical furnace model PLF 160/7 (Alser Teknik, Turkey). The final material was stored for further depiction and to use as adsorbent for the removal of arsenic from the drinking water.

\section{Characterization}

Thermogravimetric analysis (TGA) was performed on a simultaneous thermal device (SKZ1053, Shandong, China). The measurement was done under a steady flow of argon $(40 \mathrm{ml} / \mathrm{min})$, with a heating rate of $10 \mathrm{~K} / \mathrm{min}$ at a range from ambient temperature to $1150^{\circ} \mathrm{C}$. Powder X-ray diffraction (XRD) measurement was conducted on an X'Pert Pro Powder diffractometer from Analytical $(\mathrm{Cu} \mathrm{Ka}$ radiation, $40 \mathrm{kV}, 40 \mathrm{~mA})(\mathrm{D} / \mathrm{Max} 2550 \mathrm{VB}+/ \mathrm{PC})$. The X'Celerator Scientific RTMS detection unit was used for detection. Scanning electron microscope and energy dispersive X-ray spectroscopy (EDS) analyses were carried out by using IE250X-Max50 (Oxford Instruments) energy dispersive spectrometer equipped on a field emission scanning electron microscope (FESEM, JSM-6700F, JEOL, Japan). The X-ray photoemission spectroscopy (XPS) with a VG SESCALAB 210 instrument was also operated in the constant energy pass mode. The ceramic powders were measured without sputtering a thin layer of gold. Atomic absorption spectrometer Vario6 (AnalytikJena) and argon (pure 99.95\%) were used for arsenic analysis.

\section{Sample measurement}

Water samples were collected with standard procedure of sampling to evaluate the true grade of water quality for the correctives procedures as a result. The samples were collected from different located Northern Districts of Punjab Province, Pakistan and standard methods were utilized for as concentration in water quality laboratory office PCRWR Lahore for analysis.

A stock solution of $1000 \mathrm{ppb}$ was prepared from $1000 \mathrm{ppm}$ As CRM by taking $1 \mathrm{ml}$ and diluting to $1000 \mathrm{ml}$. This stock solution was diluted to $100 \mathrm{ppb}$ and then $5,10,15,20,25$ and $30 \mathrm{ppb}$ standards were prepared from the $100 \mathrm{ppb}$ by M1V1/M2V2 dilution formula. $30 \mathrm{~g}$ sodium borohydride $(\mathrm{NaBH} 4)$ and $10 \mathrm{~g} \mathrm{NaOH}$ was weigh and dissolved in $500 \mathrm{ml}$ distilled water in measuring flask and then diluted up to $1000 \mathrm{ml}$.

\section{Analysis}

The samples were analyzed on atomic absorption spectrophotometer at hydride mode. The hydride technique makes use of fact that the hydrogen liberated in the reaction of sample solutions with sodium borohydride which combines metal ions to form gaseous hydrides. These are carried to the hot quartz cell by the carrier gas and decomposed by collision process in a series of steps, until free arsenic atoms were obtained [28].

In order to make reducing solution (reluctant), $15 \mathrm{~g}$ sodium borohydride $(\mathrm{NaBH} 4)$ and $5 \mathrm{~g}$ sodium hydroxide $(\mathrm{NaOH})$ was taken and dissolved in $500 \mathrm{ml}$ distilled water in a conical flask. This reagent was used as reducing agent for arsenic analysis. The hydride system consisting of a basic unit was operated and controlled by PC basic unit consists of three accessories. Include batch module, single channelperistaltic pump and gas valve box. The gas valve box supplied argon gas for scavenging and for transporting the metal hydride to the system. Pressure of the argon gas cylinder was adjusted at 3-5 bars. After attiring the necessary temperature $950^{\circ} \mathrm{C}$ reducing agent was fed by the peristaltic pump. New method of calibration was developed using these standards under the operation of software, and then the method developed was loaded for analysis of actual samples. By using these standards and sodium borohydride reagent the calibration curve is made which has $\mathrm{R}^{2}$ value $=0.997$. A $10-\mathrm{ml}$ sample was taken in a reaction cell and $1 \mathrm{ml}$ of concentrated $\mathrm{HCl}$ was dispensed into sample and reaction cell was adjusted properly at its place. Calibrated standards of arsenic with concentrations 5, 10, 15, 20, 25 and $30 \mathrm{ppb}$ were prepared. [29] After calibration, first blank then known concentration standard and pre-analyzed sample was run. The results of standards and pre-analyzed sample were measured according to known concentration. After the satisfaction of instrument calibration, samples were analyzed. The detection limit of AAS Vario 6 was 0.03 ppb.

\section{Adsorption and kinetic measurement}

A stock arsenic $1000 \mathrm{ppb}$ solution was prepared and further diluted to different concentration ranging from (20 ppb to $200 \mathrm{ppb}$ ). Each $25-$ 
$\mathrm{ml}$ conical flask having $15 \mathrm{ml}$ of the solution of the given concentration, $0.02 \mathrm{~g}$ of the nano-ferrite was added. These solutions were shaken in an orbital shaker at $313 \mathrm{~K}$ for an optimized time of 45 minutes. The residues were separated by filtration and the filtrates were analyzed for arsenic concentration. Optimized concentration (100 $\mathrm{ppb)}$ of arsenic was chosen for kinetic measurement. In a typical experiment, twelve conical flasks containing $25 \mathrm{ml}$ of $100 \mathrm{ppb}$ arsenic solution and $0.02 \mathrm{~g}$ of the Nano ferrite were shaken in an orbital shaker at $313 \mathrm{~K}$. These flasks were taken out at different intervals of time (5, $10,15,20,25,30,35,40,45,50,55$ and 60 minutes) and analyzed for equilibrium arsenic concentration.

\section{Nickle Ferrite Adsorption Measurement}

The lattice constant, unit cell volume, crystallite size, $\mathrm{x}$-ray density ( $\rho$ x-ray), measured density $(\rho \mathrm{m})$ and porosity $(\mathrm{P})$ were calculated according to the following equations.

$$
\begin{aligned}
& \frac{1}{d^{2}}=\frac{h^{2}+k^{2}+l^{2}}{a^{2}} \\
& \mathrm{v}=\mathrm{a} 3 \\
& D=\frac{k \lambda}{\beta \cos \theta}
\end{aligned}
$$

(3)

$$
\begin{aligned}
& \rho_{x-\text { ray }}=\frac{Z M}{N_{A} V} \\
& \rho_{m}=\frac{m}{\pi r^{2} h} \\
& p(\%)=\left(1-\frac{\rho_{m}}{\rho_{x-\text { ray }}}\right) \times 100
\end{aligned}
$$

Where $\mathrm{d}$ is the line spacing, $\mathrm{hkl}$ are the miller indices, $\mathrm{a}$ is the lattice constant and $\mathrm{K}$ is the Scherer's constant (0.9), $\lambda$ is the $\mathrm{x}$-rays wavelength (1.5418 $\AA$ ), $\beta$ is the full width at half 167 maxima (FWHM) and $\theta$ is the Bragg's angle, respectively, $M, N A, V, Z, m, r$ and indicates the nickel ferrite molar mass, Avogadro's number, unit cell volume, formula units (8), pellet mass, 169 radius and pellet thickness, respectively.

The amount of adsorbate adsorbed per gram of adsorbent at equilibrium (qe) was determined by (Equation 7) [30].

$$
Q_{e}=\frac{v}{m}\left(c_{o}-c_{e}\right)
$$

Where $\mathrm{Co}, \mathrm{Ce}, \mathrm{V}$ and $\mathrm{m}$ are the initial concentration (ppb), residual concentration at equilibrium,

solution volume (L) and mass of nickel ferrites nanoparticles (g), respectively.

\section{Isothermic models measurement}

Mathematical isothermic models well explained the equilibrium relationship between nickel ferrites and arsenic concentrated solution. Equilibrium correlation data by empirical equations was done by Freundlich and Langmuir models for well adsorption operation and practical design. Both the isotherms constant values described the affinity and surface features of $180 \mathrm{NiFe}_{2} \mathrm{O}_{4}$ while the models different parameters expressed molecular distribution phenomena.

The linearized forms are presented in Equations (8) and (9), respectively.

$$
\begin{aligned}
& \operatorname{In} Q_{e}=\operatorname{In} K_{F}+\frac{1}{n} \operatorname{Inc} c_{e} \\
& \frac{{ }_{e}{ }_{e}}{Q_{e}}=\frac{1}{k_{L}}+a L \frac{{ }^{c} e}{k_{L}} \\
& Q_{m}=\frac{K_{L}}{a_{L}}\left(\frac{\mu g}{g}\right) \\
& R_{L}=\frac{1}{1} a L C o
\end{aligned}
$$

$\mathrm{K}_{\mathrm{f}}$ is the Freundlich constant $(\mathrm{L} / \mu \mathrm{g}), 1 / \mathrm{n}$ is relative distribution of energy site obtained from slope and intercept of plot of ln qe vs $\ln \mathrm{Ce}$, $\mathrm{KL}$ is the Langmuir adsorption constant $(\mathrm{L} / \mu \mathrm{g})$ related to the energy of adsorption and $\mathrm{aL}$ is the Langmuir constant which shows binding forces. The values of $\mathrm{KL}$ and aL were computed from slop and intercept of Langmuir plot (Ce/qe vs $\mathrm{Ce}$ ) and qm indicate adsorption capacity. In (Equation 11) RL indicated isothermal shape [31]. Co and aL is the initial concentration $(\mathrm{mg} / \mathrm{L})$ and 192 Langmuir constants related to energy of adsorption $(\mathrm{L} / \mathrm{mg})$, respectively.

\section{Results and Discussion}

\section{Thermogravimetric analysis of prepared nanoparticles}

Thermo gravimetric analyses (TGA) were escorted to examine the weight dilapidation in synthesized As material on heating. The TG curve for the unannealed sample of nickel ferrite $\left(\mathrm{NiFe}_{2} \mathrm{O}_{4}\right)$ is shown in Figure 1.

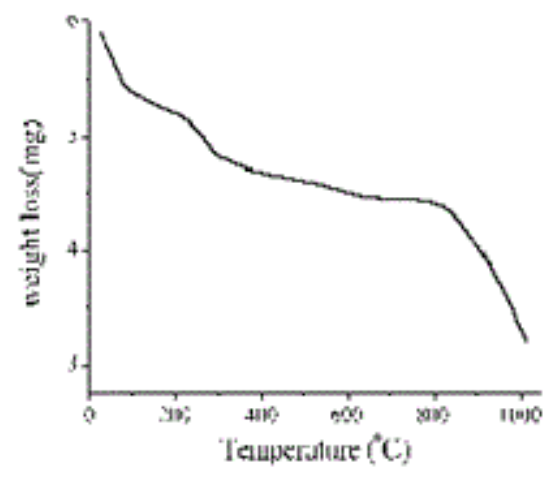

Figure 1: TGA Thermogram for the Unannealed Sample of Nickel Ferrite.

The first weight loss up to $100^{\circ} \mathrm{C}$ is due to the loss of water from the arsenic synthesized material. The weight loss from 100 to $250^{\circ} \mathrm{C}$ may 
be due to the removal of hydrated water. The other loss from 300 to $650^{\circ} \mathrm{C}$ is accredited to the formation of oxides of various metals from their hydroxides. At about $850 \mathrm{C}$ weight loss is due to the conversion of oxides into spinel cubic structure of nickel ferrite. So finally, the sample was annealed at $900^{\circ} \mathrm{C}$ to obtain the pure cubic phase of the material (Scheme 1). The present thermal analysis is in close agreement with the reported literature values of similar metal ferrites [31,32]. The schematic diagram of the said materials given below:

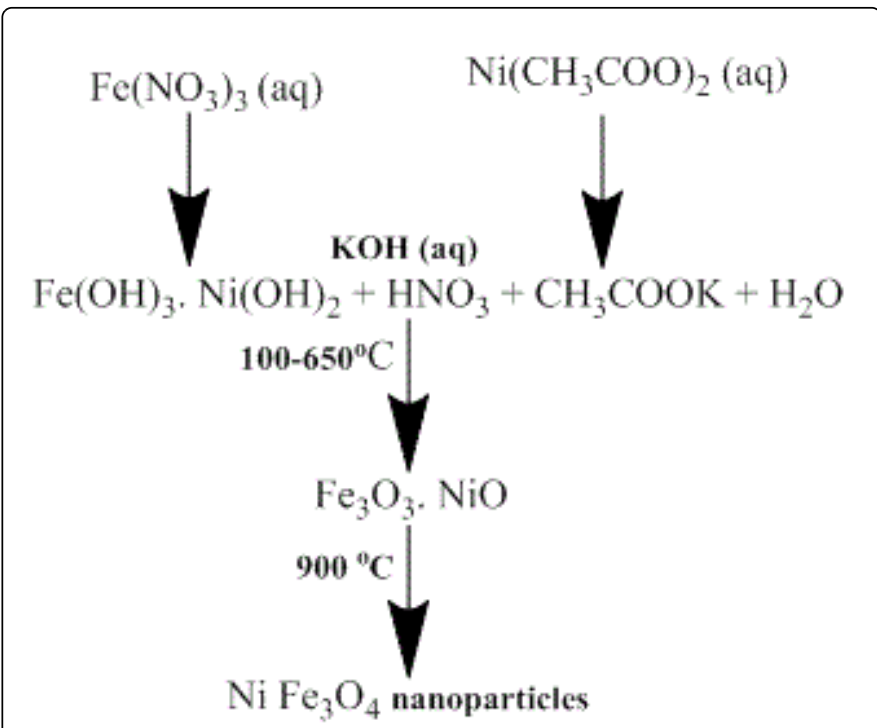

Scheme 1: Chemical Process for the Synthesis of $\mathrm{NiFe}_{2} \mathrm{O}_{4} \mathrm{NPs}$.

\section{Synthesized Nickel Ferrite Structural Analysis}

All lattice parameters were calculated from the XRD data. The powder $\mathrm{x}$-ray diffraction analysis has been used to confirm the structure of the nickel ferrite and its purity. The XRD patterns for the nickel ferrite before and after adsorption are shown in Figure 2. All the peaks in Figure $2 \mathrm{a}$ labeled are perfectly in step with the standard pattern (ICSD 00-003-0875) which assert the model of single spinel phase of the nickel ferrite. The peaks at $2 \theta=30.3,35.7,43.4,57.5$ and $63.0^{\circ}$ are corresponds to Miller Indices (220), (331), (400), (511) and (440), respectively. The absence of any other peak in the pattern imply that the synthesize materials are pure while the tiny peak labeled with arrow $(\uparrow)$ indicated very little impurity of the material. Most intense, broad and diffracted peak at 331 reflected average crystallite size and smaller $\mathrm{NiFe}_{2} \mathrm{O}_{4}$ nanoparticles.

The lattice constant (a) and cell volume (V) were found to be $8.32 \AA$ and $575.93 \AA$ range. The calculated average crystallite size is found in the range of $42 \mathrm{~nm}$. The crystallite size is smaller as compare to report earlier. The tiny crystallite size confirmed $\mathrm{NiFe}_{2} \mathrm{O}_{4}$ high surface area and beneficial as removal from aqueous environment. The high $\mathrm{x}$-ray density $5.2 \mathrm{~g} \mathrm{~cm}^{-3}$ than that of calculated density $\left(3.4 \mathrm{gcm}^{-3}\right)$ attributed to the presence of pores in the material. The percent purity was found $35 \%$. The high charge porosity adsorbs maximum arsenic concentration from aqueous solution.

The XPS spectra of $\mathrm{NiFe}_{2} \mathrm{O}_{4}$ exhibited $\mathrm{Fe} 2 \mathrm{p}$ peaks at $711.32 \mathrm{eV}$. One small peak also arised at $8.1 \mathrm{eV}$ which approves the presence of $\mathrm{Fe}^{3+}$ $[33,34]$. Both these peaks confirm the $\mathrm{Fe}^{3+}$ and $\mathrm{Fe}^{2+}$ oxidation state in $\mathrm{NiFe}_{2} \mathrm{O}_{4} \cdot \mathrm{Fe}^{2+}+2 \mathrm{p} 3 / 2$ peak at $709.5 \mathrm{eV}$ is associated with $6.0 \mathrm{eV}$ while
$\mathrm{Fe}^{3+}+2 \mathrm{p} 3 / 2$ peak at $711.2 \mathrm{eV}$ is associated with $8.0 \mathrm{eV}$ [35]. The difference between $\mathrm{Fe}^{2+}$ and $\mathrm{Fe}^{3+}$ Due to photoemission of Fe which has $\mathrm{d} 6$ and $\mathrm{d} 5$ states. The decomplexity of $\mathrm{Fe} 2 \mathrm{p} 3 / 2$ peak shows that the $\mathrm{Fe}^{3+}$ species occur in tetrahedral at higher binding energy while in octahedral at lower binding energy [36].

Post-adsorption XRD pattern analysis for nickel ferrite is exposed in Figure 2. All the peaks in this pattern are same that were exposed in the pre-adsorption material except a diminutive peak at 510 labeled as $(\uparrow)$. This peak may be assigned for the arsenic as confirmed by the standard pattern (ICSD 00-001-0760). This also explained well arsenic adsorption by the nickel ferrite.

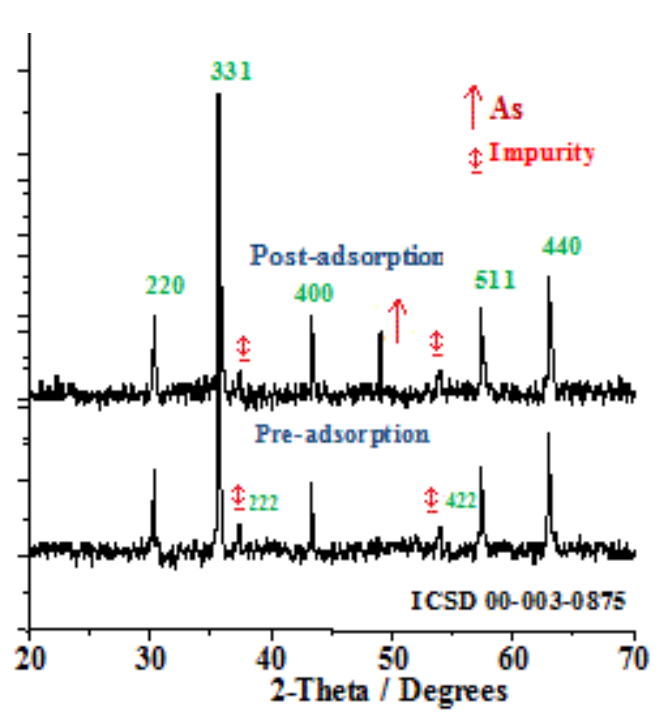

Figure 2: X-Ray Diffraction Patterns of the Samples of the Nickel Ferrite $\left(\mathrm{NiFe}_{2} \mathrm{O}_{4}\right)$. (A) Pre- Adsorption and (B) Post-Adsorption of As.

\section{Synthesized nickel ferrite energy dispersive $X$-ray fluorescence (ED-XRF) analysis}

The composition of the annealed nickel ferrite was confirmed by the energy dispersive spectroscopy (EDS) and its spectrum is shown in Figure 3. It is clear from the spectrum that peaks are correlated to the nickel, iron and oxygen. A small peak for the carbon has also been observed which may be from the atmosphere. The absence of any other element except those present in the material confirmed that there is no other contamination. The nickel and iron was found to be 1.03 and 2.06 which is in good accord with the nominal opus as was kept.

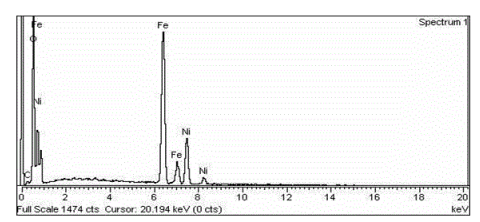

Figure 3: EDS Spectrum for the Annealed Nickel Ferrite Material. 


\section{Synthesized nano ferrites morphology and microstructure analysis}

The SEM images shown in Figure $4 \mathrm{a}$ and $4 \mathrm{~b}$ were obtained before and after arsenic adsorption in order to investigate synthesized nickel ferrite. The SEM image for the $\mathrm{NiFe}_{2} \mathrm{O}_{4}$ before the adsorption of arsenic (Figure 4a) shows that the surface is porous which is beneficial for the adsorption process. The particles are in the range of 40-70 nm and some of the particles are agglomerated into larger particles. The surface become smooth and the pores are filled by the adsorbate after the adsorption process as is indicated by Figure $4 \mathrm{~b}$. Pure PANI, substituted nickel ferrite and their composites shows the formation of flat and horizontal surface, while their composites shows that the NPs are decorated on the surface of PANI which increases the porosity in composite and the shape of NPS is plump with $40-50 \mathrm{~nm}$ particle size, which is useful for the adsorption. Some of the Pure PANI, substituted nickel ferrite particles agglomerate into big round particles [37]. Nickel nanoparticles deposited on ITO substrate illustrated monodisperse nanoparticles with a fairly uniformity with $20 \mathrm{~nm}$ particle size is also suitable in adsorption. So, the synthesized substituted $\mathrm{NiFe}_{2} \mathrm{O}_{4}$ can be used as adsorbent for the removal of arsenic from drinking water [38]. The XRD results also indicate that the material can be used for the removal of arsenic.
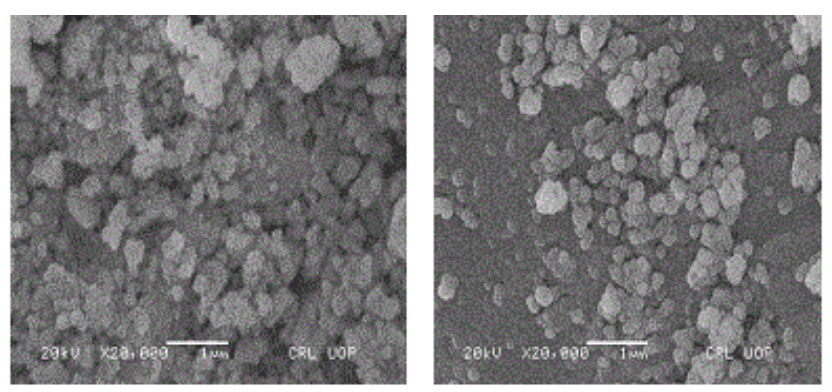

Figure 4: SEM Images for the Nickel Ferrite. (a) Pre-adsorption (b) Post-adsorption of As.

\section{Nano ferrites effect on arsenic adsorption}

The interaction of arsenic metal adsorption results on nickel ferrites nanoparticles determined by different concentration. The interaction of water molecule with $\mathrm{NiFe}_{2} \mathrm{O}_{4}$ nano-particles has been described by the adsorption properties and equilibrium data [39].

The equilibrium saturation capacity of arsenic on nickel ferrites nanoparticles is given in Figure 1, showing that values of qe increase with the increase in initial dye concentrations. Values of $\mathrm{Ce}$ and qe are given in Table 1.

\section{Isothermal adsorption}

Figure 5 show S-type adsorption behavior of arsenic on nickel ferrites nanoparticle surface. The adsorption isotherm starts initially convex to the equilibrium concentration to the dye solution. The adsorption in the beginning is low, followed by sharp rise in adsorption. The initial low adsorption indicates competition between the solute with that of solvent molecules. But as concentration of solute is increased, the competition with solvent is reduced and the additional amount of the solute is then simply adsorbed. The absence of clear plate shows that multimolecular layer formation starts even before the formation of mono molecular layer is complete [40]. Adsorbate produce a surface that has almost same affinity for the metal as that of the bare surface. The further rise in adsorption isotherms represents the development of fresh surface on which further adsorption can occur.

\begin{tabular}{|l|l|l|l|l|l|}
\hline \multicolumn{5}{|l|}{ Standard sample } & \multicolumn{3}{l|}{ Tested sample } \\
\hline $\begin{array}{l}\mathbf{C}_{0}(\mu \mathrm{g} / \mathrm{L}) \\
\text { standard }\end{array}$ & $\mathrm{C}_{\mathrm{e}}(\mu \mathrm{g} / \mathrm{L})$ & $\mathrm{q}_{\mathrm{e}}(\mu \mathrm{g} / \mathrm{g})$ & $\mathrm{C}_{0}(\mu \mathrm{g} / \mathrm{L})$ & $\mathrm{C}_{\mathrm{e}}(\mu \mathrm{g} / \mathrm{L})$ & $\mathrm{q}_{\mathrm{e}}(\mu \mathrm{g} / \mathrm{g})$ \\
\hline 20 & 0.31 & 2.461 & 2.53 & 0.246 & 0.305 \\
\hline 40 & 0.47 & 4.941 & 4.54 & 0.569 & 0.510 \\
\hline 60 & 0.61 & 7.423 & 6.06 & 0.984 & 0.634 \\
\hline 80 & 0.75 & 9.906 & 10.12 & 1.960 & 1.020 \\
\hline 100 & 0.87 & 12.391 & 22.78 & 5.578 & 2.150 \\
\hline 120 & 0.96 & 14.88 & - & - & - \\
\hline 140 & 1.24 & 17.345 & - & - & - \\
\hline 160 & 1.4 & 19.825 & - & - & - \\
\hline 180 & 1.57 & 22.304 & - & - & - \\
\hline 200 & 1.66 & 24.793 & - & - & - \\
\hline
\end{tabular}

Table 1: Adsorption Data of Arsenic Metal from Standard Samples on Nickel Ferrites Nanoparticles and in Tested Samples on Nickel Ferrites Nanoparticles.
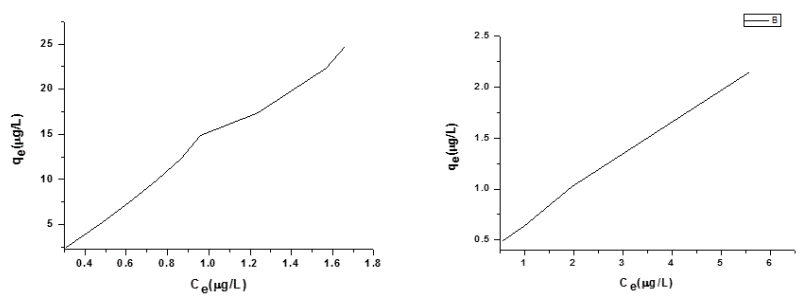

Figure 5: Adsorption Isotherm of Arsenic (A) Standard Sample and (B) Tested Sample on Nickel Ferrite Nanoparticles.

\section{Isothermal results}

The intercept which is $1 / K_{L}$ and the slope which is $a_{L} / K_{L}$ of plot Ce/qe against Ce give the values of $K_{L}$ and $a_{L}$. The linear plots of specific adsorption Ce/qe against the equilibrium Ce for two samples (standard and tested) are shown in Figure 6. The isotherm constants aL and $\mathrm{KL}$, and the equilibrium capacities $\mathrm{q}_{\max }$ are presented in Table 2 . Values of aL indicate strong binding while dimensionless constant separation factor $\left(\mathrm{R}_{\mathrm{L}}\right)$ confirmed favorable arsenic adsorption (Table 2). The Freundlich model empirical (Equation 8) is used to analyze experimental adsorption data of arsenic metal on nickel ferrites nanoparticles. This model well described the heterogenous surface adsorption with a uniform energy distribution and reversible adsorption. This predicted that arsenic concentration on the ferrites 
increased with the augmented in aqueous arsenic concentration. Examination of the linear Freundlich isotherm plots (Figure 7) suggested that it is much better fit than the Langmuir model. Table 2 shows the Freundlich constants for Arsenic metal on nickel ferrites nanoparticles. Values of $1 / \mathrm{n}<1$ represent favorable adsorption conditions [41].

\begin{tabular}{|l|l|l|l|l|l|l|l|l|}
\hline Adsorbents & \multicolumn{3}{|l|}{ Langmuir model } & \multicolumn{4}{l|}{ Freundlich model } \\
\hline & $\begin{array}{l}\mathbf{q m} \\
(\boldsymbol{\mu g} / \mathbf{g})\end{array}$ & $\begin{array}{l}\mathbf{K L}(\mathbf{L} / \mathbf{g} \\
\mathbf{)}\end{array}$ & $\begin{array}{l}\mathbf{a L} \mathbf{( L /} \\
\mathbf{\mu g})\end{array}$ & $\mathbf{R}_{\mathbf{L}}$ & $\mathbf{R}^{2}$ & $\mathbf{n}$ & $\begin{array}{l}\mathbf{K F} \\
\mathbf{( L /} \mathbf{\mu g})\end{array}$ & $\mathbf{R}_{2}$ \\
\hline $\begin{array}{l}\text { Standard } \\
\text { sample }\end{array}$ & 30.40 & 9.30 & 0.30 & 0.57 & 0.49 & 0.73 & 0.96 & 0.98 \\
\hline $\begin{array}{l}\text { Tested } \\
\text { sample }\end{array}$ & 3.51 & 0.94 & 0.28 & 0.59 & 0.85 & 1.56 & -4.50 & 0.99 \\
\hline
\end{tabular}

Table 2: Langmuir and Freundlich Parameters for the Adsorption of Arsenic Metal on Nickel Ferrite Nanoparticles.
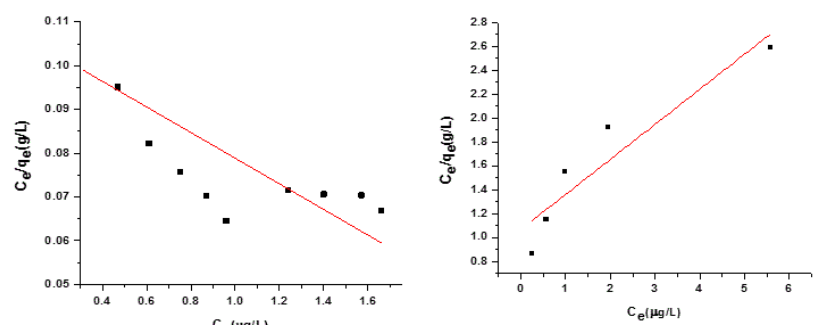

Figure 6: Langmuir Adsorption Model of Arsenic from (A) Standard Sample and (B) Tested Sample on Nickel Ferrites.
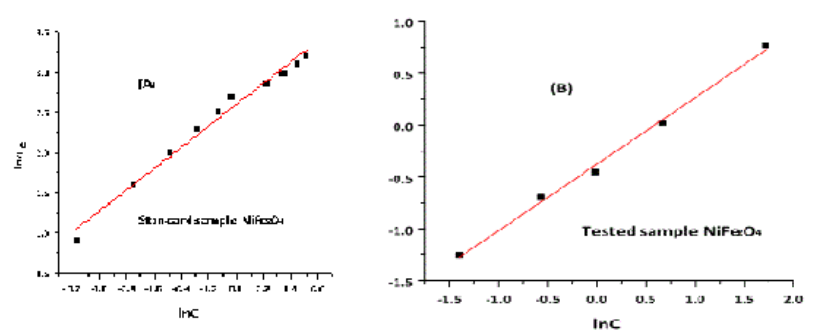

Figure 7: Freundlich Adsorption Model of Arsenic from (A) Standard Sample and (B) Tested Samples on Nickel Ferrites Nanoparticles.

\section{Conclusion}

The Nickle Ferrite was productively synthesized by using simple and economic co-precipitation method to control the nanoparticle size. The XRD confirmed the spinel structure of the nickel ferrite. The crystalline size estimated by Scherer's formula was in the average range of $42 \mathrm{~nm}$ which is in agreement to earlier reported studies. The SEM showed that the particles are in round shaped and have clear boundaries. The EDS analysis confirmed the ratio between nickel and iron. The XPS investigated the $\mathrm{Fe}^{3+}$ species in octahedral and tetrahedral locations and presence of $\mathrm{Ni}$ ions in $\mathrm{NiFe}_{2} \mathrm{O}_{4} \mathrm{NPs}$. This material was employed for the removal of arsenic from the drinking water. The values of correlation coefficient of Freundlich isotherm is much higher than the other materials used for the removal of arsenic from aqueous media. The results showed that the $98 \%$ of the arsenic has been removed from the drinking water which is much higher than that of another adsorbents Table 3. [42-44] The high adsorption capacity and the \% age removal of arsenic from drinking water by nickel ferrite suggest that this material have variety of potential applications and can be successfully used for the removal of arsenic.

\begin{tabular}{|l|l|l|l|}
\hline Adsorbents & As (III)\% removal & As (V) \% removal & References \\
\hline $\mathrm{Fe}_{2} \mathrm{O}_{3}$ & 90.0 & 96.5 & 42 \\
\hline $\begin{array}{l}\mathrm{Mg}_{0} \cdot 27 \\
\text { ultrafine }\end{array}$ & 98.0 & 98.0 & 43 \\
\hline$\alpha-\mathrm{Fe}_{2} \mathrm{O}_{3}$ ultrafine & 28.0 & 28.0 & 43 \\
\hline $\mathrm{MnFe}_{2} \mathrm{O}_{4}$ & 93.2 & 90.4 & 44 \\
\hline $\mathrm{CoFe}_{2} \mathrm{O}_{4}$ & 83.5 & 73.8 & 44 \\
\hline $\mathrm{NiFe}_{2} \mathrm{O}_{4}$ & 98.0 & 98.0 & Present study \\
\hline
\end{tabular}

Table 3: Comparison of Adsorption Efficiency (\%) of $\mathrm{NiFe}_{2} \mathrm{O}_{4}$ with other Metal Ferrites.

\section{Acknowledgments}

This research is supported by the National Natural Science Foundation of China (21174112), the Fundamental Research Funds for the Central Universities (3102015BJ (II) JGZ026) and Aerospace Science and Technology Innovation Foundation.

\section{References}

1. International Program on Chemical Safety, Inter-Organization Programme for the Sound Management of Chemicals, \& World Health Organization. (2010). WHO Recommended Classification of Pesticides by Hazard and Guidelines to Classification 2009. World Health Organization.

2. Parajuli K (2013) Rural methods to mitigate arsenic contaminated water.

3. Vu KB, Kaminski MD, Nunez L (2003) Review of arsenic removal technologies for contaminated ground waters (No. ANL-CMT-03/2). Argonne National Lab, IL, USA.

4. Luzi S, Berg M, Pham TKT, Pham HV, Schertenleib R (2004) Household sand filters for arsenic removal. Swiss Federal Institute for Environmental Science and Technology (EAWAG), Duebendorf, Switzerland.

5. http://www.unicef.org/supply/index_cpe_water.html

6. Zhao J, Zhu J, Zhong X, Ou D, Zhou H (2007) A novel fabrication and properties investigation of permalloy- $\mathrm{SiO}_{2}$ granular films with induced anisotropy. Mat Lett 61: 491-495.

7. Hu J, Li LS, Yang W, Manna L, Wang LW, et al. (2001) Linearly polarized emission from colloidal semiconductor quantum rods. Sci 292: 2060-2063.

8. Słoczyński J, Janas J, Machej T, Rynkowski J, Stoch, J (2000) Catalytic activity of chromium spinels in SCR of $\mathrm{NO}$ with $\mathrm{NH}_{3}$. App Cat B Envi 24: 45-60.

9. Pena MA, Fierro JLG (2001) Chemical structures and performance of perovskite oxides. Chem Rev 101: 1981-2018.

10. Ajayan PM, Redlich P (1997) Structure of carbon nanotubebased nanocomposites. J of Micro 185: 275-282.

11. Baykal A, Kasapoğlu N, Durmuş Z, Kavas H, Toprak MS, et al. (2009) CTAB-Assisted Hydrothermal Synthesis and Magnetic Characterization 
Citation: Idrees M, Batool S (2017) Enhanced Aqueous Arsenic Absorbing Substituted Spinel Nickel Ferrite $\left(\mathrm{NiFe}_{2} \mathrm{O}_{4}\right) \mathrm{Nano}^{\mathrm{Particles}}$. Adv Recycling Waste Manag 2: 123. doi:10.4172/2475-7675.1000123

Page 7 of 7

of $\mathrm{Ni}_{\mathrm{x}} \mathrm{Co}_{\{1-\mathrm{x}\}} \mathrm{Fe}_{2} \mathrm{O}_{4}$ Nanoparticles (x=0.0, 0.6, 1.0). Turk J Chem 33: $33-45$.

12. Gunjakar JL, More AM, Gurav KV, Lokhande CD (2008) Chemical synthesis of spinel nickel ferrite $\left(\mathrm{NiFe}_{2} \mathrm{O}_{4}\right)$ nano-sheets. App Surf Sci 254: 5844-5848.

13. Wang X, Yang G, Zhang Z, Yan, L, Meng J (2007) Synthesis of strong magnetic Nano sized black pigment $\mathrm{Zn}_{\mathrm{x}} \mathrm{Fe}_{(3-\mathrm{x})} \mathrm{O}_{4}$. Dyes and Pigm 74: 269-272.

14. Baykal A, Kasapoğlu N, Köseoğlu Y, Toprak MS, Bayrakdar H (2008) CTAB-assisted hydrothermal synthesis of $\mathrm{NiFe}_{2} \mathrm{O}_{4}$ and its magnetic characterization. J of All and Com 464: 514-518.

15. Amrousse, R, Katsumi $T$ (2012) Substituted ferrite $\mathrm{M}_{\mathrm{x}} \mathrm{Fe}_{1-\mathrm{x}} \mathrm{Fe}_{2} \mathrm{O}_{4}(\mathrm{M}=$ $\mathrm{Mn}, \mathrm{Zn}$ ) catalysts for $\mathrm{N}_{2} \mathrm{O}$ catalytic decomposition processes. Cat Comm 26: 194-198.

16. Alarifi A, Deraz NM, Shaban S (2009) Structural, morphological and magnetic properties of $\mathrm{NiFe}_{2} \mathrm{O}_{4}$ nano-particles. J of Alli and Com 486: 501-506.

17. Manova E, Tsoncheva T, Paneva D, Mitov I, Tenchev K, et al (2004) Mechanochemically synthesized nano-dimensional iron-cobalt spinel oxides as catalysts for methanol decomposition. App Cat Gen 277: 119-127.

18. Ferreira TAS, Waerenborgh JC, Mendonça MHRM, Nunes MR, Costa FM (2003) Structural and morphological characterization of $\mathrm{FeCo}_{2} \mathrm{O}_{4}$ and $\mathrm{CoFe}_{2} \mathrm{O}_{4}$ spinels prepared by a coprecipitation method. Sol Sta Sci 5: 383-392.

19. De Guire MR, O'Handley RC, Kalonji G (1989) The cooling rate dependence of cation distributions in $\mathrm{CoFe}_{2} \mathrm{O}_{4}$. J of App Phy 65: 3167-3172.

20. Li S, John VT, O'Connor C, Harris V, Carpenter E (2000) Cobalt-ferrite nanoparticles: Structure, cation distributions and magnetic properties. J of App Phy 87: 6223-6225.

21. Shafi KV, Gedanken A, Prozorov R, Balogh J (1998) Sonochemical preparation and size-dependent properties of nanostructured $\mathrm{CoFe}_{2} \mathrm{O}_{4}$ particles. Chem of Mat 10: 3445-3450.

22. Kim CS, Yi YS, Park KT, Namgung H, Lee JG (1999) Growth of ultrafine Co-Mn ferrite and magnetic properties by a sol-gel method. J of App phy 85: 5223-5225.

23. Hochepied JF, Bonville P, Pileni MP (2000) Nonstoichiometric zinc ferrite nanocrystals: syntheses and unusual magnetic properties. J of Phy Chem B 104: 905-912.

24. Kim YI, Kim D, Lee CS (2003) Synthesis and characterization of $\mathrm{CoFe} 2 \mathrm{O} 4$ magnetic nanoparticles prepared by temperature-controlled coprecipitation method. Phys B Con Mat 337: 42-51.

25. Feltin N, Pileni MP (1997) New technique for synthesizing iron ferrite magnetic nanosized particles. Langmuir 135: 3927-3933.

26. Prasad S, Gajbhiye NS (2015) Chem Eng J 264: 863-872.

27. Singh R, Singh S, Parihar P, Singh VP, Prasad SM (2015) Arsenic contamination, consequences and remediation techniques: a review. Eco and Env Saf 112: 247-270.
28. Kittel C (1976) Introduction to solid state Physics, 5th edn Wiley, pp: $39-40$.

29. Sickafus KE, Wills JM, Grimes NW (1999) Structure of spinel. JMCS 82: 3279-3292.

30. Tien C (1994) Adsorption Calculations and Modeling. ButterworthHeinemann Series 401 in Chemical Engineering.

31. Munir K, Yusuf M, Noreen Z, Hameed A, Hafeez FY, et al. (2010) Isotherm studies for determination of removal capacity of bi-metal (Ni and $\mathrm{Cr}$ ) ions by Aspergillus niger. Pak J Bot 42: 593-604.

32. Anjum S, Hameed S, Bashir F (2015) Microstructural, Structural, Magnetic and Optical Properties of Antimony Doped Cobalt Spinel Ferrites. Materials Today: Proceedings 2: 5329-5336.

33. Mahmood A, Warsi MF, Ashiq MN, Sher M (2012) Improvements in electrical and dielectric properties of substituted multiferroic $\mathrm{LaMnO} 3$ based nanostructures synthesized by co-precipitation method. Mat Res Bull 47: 4197-4202.

34. Li F, Liu X, Yang Q, Liu J, Evans DG, et al. (2005) Synthesis and characterization of $\mathrm{Ni}_{1-\mathrm{x}} \mathrm{Zn}_{\mathrm{x}} \mathrm{Fe}_{2} \mathrm{O}_{4}$ spinel ferrites from tailored layered double hydroxide precursors. Mat Res Bul 40: 1244-1255.

35. Zhang J, Shi J, Gong M (2009) Synthesis of magnetic nickel spinel ferrite Nano spheres by a reverse emulsion-assisted hydrothermal process. JSSC 182: 2135-2140.

36. Mittal VK, Chandramohan P, Bera S, Srinivasan MP, Velmurugan SVNS, et al (2006) Cation distribution in $\mathrm{Ni}_{\mathrm{x}} \mathrm{Mg}_{1-}{ }_{\mathrm{x}} \mathrm{Fe}_{2} \mathrm{O}_{4}$ studied by XPS and Mössbauer spectroscopy. Sol Stat Comm 137: 6-10.

37. Aamir M, Naeem Ashiq M, Yasmeen G, Ahmad B, Fahad Ehsan M, et al. (2016) Synthesis and characterization of polyaniline/Zr-Co-substituted nickel ferrite $\left(\mathrm{NiFe}_{1}\right.$. 2Zro. 4Co0.4O $\left.\mathrm{O}_{4}\right)$ nanocomposites: their application for the photodegradation of methylene blue. Des and Wat Treat 57: 12168-12177.

38. Prieto P, Nistor V, Nouneh K, Oyama M, Abd-Lefdil M, et al. (2012) XPS study of silver, nickel and bimetallic silver-nickel nanoparticles prepared by seed mediated growth. App Surf Sci 258: 8807-8813.

39. Giles CH, D'Silva AP, Easton IA (1974) A general treatment and classification of the solute adsorption isotherm part II Experimental interpretation. J Coll and Int Sci 47: 766-778.

40. Ko DC, Porter JF, McKay G (2000) Optimised correlations for the fixedbed adsorption of metal ions on bone char. Chem eng sci 55: 5819-5829.

41. Greer HF, Liu Y, Greenaway A, Wright PA, Zhou W (2016) Synthesis and Formation Mechanism of Textured MOF-5. Cry Gro and Des 16: 2104-2111.

42. Mayo JT, Yavuz C, Yean S, Cong L, Shipley H, et al. (2007) The effect of nano crystalline magnetite size on arsenic removal. STAM 8: 71.

43. Tang W, Su Y, Li Q, Gao S, Shang JK (2013) Superparamagnetic magnesium ferrite nano adsorbent for effective arsenic (III, V) removal and easy magnetic separation. Water Research 47: 3624-3634.

44. Zhang S, Niu H, Cai Y, Zhao X, Shi Y (2010) Arsenite and arsenate adsorption on coprecipitated bimetal oxide magnetic nanomaterials: $\mathrm{MnFe}_{2} \mathrm{O}_{4}$ and $\mathrm{CoFe}_{2} \mathrm{O}_{4}$. Chem Eng Jour 158: 599-607. 